\title{
High prevalence of prediabetes and diabetes in a population exposed to high levels of an organochlorine cocktail
}

\author{
J. Ukropec · Z. Radikova • M. Huckova • J. Koska • \\ A. Kocan • E. Sebokova • B. Drobna • T. Trnovec • \\ K. Susienkova $\cdot$ V. Labudova $・$ D. Gasperikova • \\ P. Langer $\cdot$ I. Klimes
}

Received: 4 November 2009 / Accepted: 11 January 2010 /Published online: 25 February 2010

(C) Springer-Verlag 2010

\begin{abstract}
Aims/hypothesis A heavily polluted area of Eastern Slovakia was targeted by the PCBRISK cross-sectional survey to search for possible links between environmental pollution and both prediabetes and diabetes.

Methods Associations of serum levels of five persistent organic pollutants (POPs), namely polychlorinated biphenyls (PCBs), 2,2'-bis(4-chlorophenyl)-1,1-dichloroethylene (p,p'-DDE), 2,2'-bis(4-chlorophenyl)-1,1,1-trichloro-ethane $\left(p, p^{\prime}\right.$-DDT), hexachlorobenzene (HCB) and $\beta$-hexachlorocyclohexane $(\beta-\mathrm{HCH})$, with prediabetes and diabetes were investigated in 2,047 adults. Diabetes and prediabetes
\end{abstract}

J. Ukropec and Z. Radikova are joint first authors; P. Langer and I. Klimes are joint last authors.

J. Ukropec $\cdot$ M. Huckova $\cdot$ E. Sebokova $\cdot$ D. Gasperikova $\cdot$

P. Langer $\cdot$ I. Klimes $(\bowtie)$

Diabetes Laboratory, Institute of Experimental Endocrinology (an

EU Centre of Excellence) Slovak Academy of Sciences,

Vlarska 3, 83306 Bratislava, Slovak Republic

e-mail: iwar.klimes@savba.sk

Z. Radikova $\cdot$ J. Koska

Laboratory of Human Endocrinology,

Institute of Experimental Endocrinology (an EU

Centre of Excellence) Slovak Academy of Sciences,

Bratislava, Slovak Republic

A. Kocan $\cdot$ B. Drobna $\cdot$ T. Trnovec

Department of Toxic Organic Pollutants,

Slovak Medical University,

Bratislava, Slovak Republic

K. Susienkova $\cdot$ V. Labudova

Department of Statistics, Faculty of Economic Informatics,

Economics University,

Bratislava, Slovak Republic were diagnosed by fasting plasma glucose in all participants and by OGTT in 1,220 compliant participants.

Results Our population was stratified in terms of individual POPs quintiles and associations between environmental pollution, prediabetes and diabetes were investigated. Prevalence of prediabetes and diabetes increased in a dose-dependent manner, with individuals in upper quintiles of individual POPs showing striking increases in prevalence of prediabetes as shown by OR and $95 \% \mathrm{CI}$ for PCBs (2.74; 1.92-3.90), DDE (1.86; 1.17-2.95), DDT (2.48; $1.77-3.48)$, HCB $(1.86 ; 1.7-2.95)$ and $\beta-\mathrm{HCH}(1.97 ; 1.28$ 3.04). Interestingly, unlike PCBs, DDT and DDE, increased levels of $\mathrm{HCB}$ and $\beta-\mathrm{HCH}$ seemed not to be associated with increased prevalence of diabetes. Nevertheless, individuals in the 5th quintile of the variable expressing the cumulative effect of all five POPs (sum of orders) had a more than tripled prevalence of prediabetes and more than six times higher prevalence of diabetes when compared with the 1 st referent quintile.

Conclusions/interpretation Increasing serum concentrations of individual POPs considerably increased prevalence of prediabetes and diabetes in a dose-dependent manner. Interaction of industrial and agricultural pollutants in increasing prevalence of prediabetes or diabetes is likely.

Keywords Diabetes · Persistent organochlorine pollutants · Prediabetes

Abbreviations
$\begin{array}{ll}\text { AhR } & \text { Aryl hydrocarbon receptor } \\ p, p^{\prime} \text {-DDE } & 2,2^{\prime} \text {-bis(4-chlorophenyl)-1,1-dichloroethylene } \\ p, p^{\prime} \text {-DDT } & 2,2^{\prime}-\text {-bis(4-chlorophenyl)-1,1,1-trichloro-ethane } \\ \text { FPG } & \text { Fasting plasma glucose } \\ \text { HCB } & \text { Hexachlorobenzene } \\ \beta-\mathrm{HCH} & \beta \text {-Hexachlorocyclohexane }\end{array}$




\section{PCBs Polychlorinated biphenyls}

POLL5 Variable expressing the cumulative effect of all five POPs (sum of orders)

POPs Persistent organochlorine pollutants

TCDD 2,3,7,8-Tetrachlorodibenzo- $p$-dioxin

\section{Introduction}

Among the several adverse effects of persistent organochlorine pollutants (POPs) and other environmental toxicants (e.g. nitrate, arsenic) on human health, attention has focused on impaired glucose metabolism and the prevalence of diabetes mellitus [1]. The Air Force Health Study provided the seminal observation that spraying Agent Orange, contaminated with 2,3,7,8-tetrachlorodibenzo- $p$ dioxin (TCDD), is associated with increased levels of fasting serum glucose [2]. That study also showed increased prevalence of diabetes, hyperinsulinaemia in fasted state and at $2 \mathrm{~h}$ after glucose load, and decreased insulin sensitivity in individuals with high serum TCDD levels [2-5].

Several reports based on mortality rates analysis $[6,7]$ or on self-reported diabetes also show associations between environmental pollution levels and prediabetes and/or diabetes [8-10]. However, in only few studies was diabetes diagnosed with the aid of fasting plasma glucose (FPG)

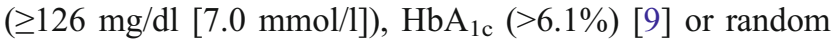
glucose level $(\geq 200 \mathrm{mg} / \mathrm{dl}=11.1 \mathrm{mmol} / \mathrm{l})$ [11-13]. Our study was conducted within the PCBRISK project in an area of Eastern Slovakia that has been subjected to heavy industrial and agricultural pollution for nearly four decades. Our previous research clearly showed very high levels of polychlorinated biphenyls (PCBs), 2,2'-bis(4-chlorophenyl)-1,1-dichloroethylene ( $p, p^{\prime}$-DDE) and hexachlorobenzene $(\mathrm{HCB})$ in environmental and human samples from this area $[14,15]$. The same is true for levels of dioxins, furans and dioxin-like PCBs [16], as well as for $\mathrm{OH}-$ and $\mathrm{MeSO}_{2}$-metabolites [17]. Moreover, in the population of this area increased thyroid volume, prevalence of thyroid antibodies, disruption of thyroid hormone level and pituitary-thyroid interrelations have been found [18-22]. More recently, an increase in adverse health signs has been reported in adults [23] as well as in newborns, infants and school children of this area, e.g. high levels of organochlorines in umbilical cord blood [24] and higher prevalence both of smaller thymic volume [25] and of increased hearing threshold [26].

The primary aim of this study was to carry out a crosssectional analysis on the association of heavy industrial and agricultural pollution with prevalence of prediabetes and diabetes as diagnosed by FPG and, in more than half of the population, by OGTT.

\section{Methods}

Participants A total of 2,047 individuals ( 835 men, 1,212 women; age range $21-75$ years) were recruited by 28 a priori selected primary care physicians from the heavily polluted east Slovakian district of Michalovce (433 men, 576 women) and from two adjacent districts of Svidnik and Stropkov (402 men, 636 women).

This was a representative sample of the population as virtually all residents have a primary care physician assigned to them on the basis of their place of residence, providing a direct link from a physician's practice to a geographical area of the district. Each of the 28 a priori selected local physicians was instructed to recruit about 60 to 100 individuals by systematic random sampling using the alphabetically ordered lists of their patients. The study was therefore able to achieve target recruitment of about $30 \%$ of participants between 21 and 40 years, and about $70 \%$ between 41 and 75 years, while keeping the ratio of men:women in the range of $40 \%$ to $60 \%$. All participants underwent a thyroid ultrasound examination and fasting blood sampling. OGTTs were performed in 1,220 compliant individuals. Plasma glucose was analysed in the fasted state, as well as at 60 and 120 min after administration of $75 \mathrm{~g}$ glucose.

This investigation was conducted according to the declaration of Helsinki, approved by the Institutional Review Board and by anonymous reviewers of the European Commission. All participants provided written informed consent.

Blood samples were centrifuged within $2 \mathrm{~h}$ after collection in a refrigerated centrifuge. Serum and plasma aliquots were frozen, transported in a portable freezer to the laboratory and stored at $-20^{\circ} \mathrm{C}$ until assayed.

Glucose Fasting as well as 1 and $2 \mathrm{~h}$ plasma glucose levels were determined using an analyser (Hitachi 901; Hitachi, Saitama-ken, Japan). Fasting plasma glucose and $2 \mathrm{~h}$ glucose were used to diagnose prediabetes (impaired fasting glucose: $\mathrm{FPG}>5.6$ but $<7.0 \mathrm{mmol} / 1$ and/or impaired glucose tolerance: $2 \mathrm{~h}$ glucose $>7.8$ but $<11.1 \mathrm{mmol} / \mathrm{l}$ ) and diabetes (FPG $>7.0 \mathrm{mmol} / \mathrm{l}, 2 \mathrm{~h}$ glucose $>11.1 \mathrm{mmol} / \mathrm{l}$ ) according to criteria of the American Diabetes Association [27]. Present history of diabetes as diagnosed and already treated by a physician was found in 96 individuals.

Polychlorinated biphenyls and pesticides We determined 15 PCB congeners (IUPAC [International Union of Pure and Applied Chemistry] numbers 28, 52, 101, 105, 114, 118, 123, $138^{+163}, 153,156^{+171}, 157,167,170,180$ and 189) and also 
$p, p^{\prime}$-DDE, 2,2'-bis(4-chlorophenyl)-1,1,1-trichloro-ethane $\left(p, p^{\prime}\right.$-DDT), HCB and $\beta$-hexachlorocyclohexane $(\beta-\mathrm{HCH})$ in serum using a high-resolution gas chromatography device (HP 6890; Agilent, Santa Clara, CA, USA) equipped with a Ni-63 micro-electron capture detector and a 60-m DB-5 capillary column (J\&W Scientific, Folsom, CA, USA) [14, 15].

For less abundant congeners, values corresponding to half the limit of detection were used. These varied from $3.9 \mathrm{ng} / \mathrm{g}$ lipid for PCB-157 to $7.5 \mathrm{ng} / \mathrm{g}$ lipid for PCB-52. For organochlorine pesticides the limits of detection were between $2.8 \mathrm{mg} / \mathrm{g}$ for $\gamma-\mathrm{HCH}$ and $7.4 \mathrm{ng} / \mathrm{g}$ for $\beta-\mathrm{HCH}$. The sum of all 15 individual PCB congeners was calculated as the sum of PCBs including half the limit of detection for non-detected PCBs.

Enzymatic methods based on the determination of total cholesterol, non-esterified cholesterol, phospholipids and triacylglycerol were used to determine individual and total lipids in serum, and the level of organochlorines was then adjusted to the total lipid level.

Statistical evaluation To analyse the associations between serum levels of five individual POPs (PCBs, $p, p^{\prime}$-DDE, $\mathrm{HCB}, p, p^{\prime}$-DDT and $\left.\beta-\mathrm{HCH}\right)$ and prediabetes and/or diabetes, logistic regression analysis was used. Multivariate adjusted odds ratios were calculated with SAS Enterprise Miner 5.2 (SAS, Cary, NC, USA). Adjustable variables were age (continuous), sex and BMI (categorical). The outcome variable was either prediabetes or diabetes. Analysed POPs entered the models as categorical variables transformed to five categories (1st-5th quintiles) according to individual POPs levels. For each POP, the reference group consisted of individuals belonging to the first quintile (i.e. $20 \%$ of individuals with the lowest levels of POP). POPs entered the model either separately or simultaneously in order to identify their individual contribution to the outcome variable.

To evaluate the cumulative effects of all five POPs, we summed the ranks of each POP and the summary values were categorised by cut-off points 20th, 40th, 60th and 80th percentile values, resulting in a variable expressing the cumulative effect of all five POPs (sum of orders; POLL5).

\section{Results}

Prediabetes in individuals with increased circulating $P O P S$ Detailed phenotyping showed that our cohort consisted of 296 patients with diabetes, 973 individuals with prediabetes and 778 individuals with normal FPG. All study participants were stratified to quintiles according to levels of each individual POP. Logistic regression analysis using a stepwise factor selection showed independent association of individual POPs with prediabetes, which was independent of age, sex and BMI (Tables 1 and 2). Moreover, a gradual increase in the levels of each individual POP was associated with a stepwise increase in prevalence of prediabetes. Thus the prevalence was $69.8 \%$, $59.9 \%, 82.3 \%, 80.8 \%$ and $72.5 \%$ higher in individuals in the 5th quintile of PCBs, HCB, $p, p^{\prime}$-DDE, $p, p^{\prime}$-DDT and $\beta-\mathrm{HCH}$, respectively, when compared with the 1 st (reference) quintile. Synergic interactions between individual POPs are likely, since partial correlation coefficients between $p, p^{\prime}$-DDE and $p, p^{\prime}$-DDT, as well as between HCB and $\beta$-HCH $(0.505$ and 0.369 , respectively) indicated their significant association. Table 1 clearly shows that individuals in the upper three quintiles of PCBs, $p, p^{\prime}$-DDE and $p, p^{\prime}$-DDT showed a significantly elevated risk of being glucose-intolerant or having diabetes with respective ORs of 2.74, 2.49 and 2.48 in the 5th quintile. The same was true for the 4 th and 5 th quintile of $\mathrm{HCB}$ as well as for the 5 th quintile of $\beta-\mathrm{HCH}$ (Table 1, Fig. 1).

To determine possible interactions between each of the individual POPs, the levels of all individual POPs categorised to quintiles were subjected to stepwise factor selection analysis. A significant effect of PCBs on the prevalence of prediabetes was shown, while the other pollutants were removed from the model due to low levels of significance (Table 2).

Use of the variable POLL5 enabled us to evaluate the collective effect of all five individual POPs on the prevalence of prediabetes. Interestingly, individuals in the $3 \mathrm{rd}$, 4th and 5th quintiles of POLL5 had a higher probability of suffering from prediabetes than that shown for each individual POP, further indicating possible synergistic effects of industrial and agricultural pollutants (Table 1, Fig. 1).

Diabetes in individuals with increased circulating POPS Identical analyses as previously described for prediabetes were applied to determine associations of POPs with the prevalence of diabetes. They clearly showed significant associations of PCBs, $p, p^{\prime}$-DDT and $p, p^{\prime}$-DDE with prevalence of diabetes; associations were independent of age, sex and BMI (Table 3). Prevalence of diabetes among individuals in the 5th quintile of PCBs, HCB, $p, p^{\prime}$-DDE, $p, p^{\prime}$-DDT and $\beta$-HCH increased 3-, 4.1-, 4.4-, 5.5- and 4.4-fold respectively, when compared with the 1st (reference) quintile.

We further observed that individuals in the upper three quintiles of $p, p^{\prime}$-DDT had a significantly elevated risk of developing diabetes, with ORs 1.84, 2.51 and 2.49 for the 3rd, 4th and 5th quintiles, respectively (Table 3 ). This was also true for the 4th and 5th quintiles of PCBs and for the 5th quintile of $p, p^{\prime}$-DDE (Table 3), whereas levels of HCB and $\beta-\mathrm{HCH}$ adjusted for age, sex and BMI seemed not to be associated with increased prevalence of diabetes. 
Table 1 Effect of different POPs on the prevalence of prediabetes

\begin{tabular}{|c|c|c|c|c|c|}
\hline \multirow[t]{2}{*}{ Analyte } & \multicolumn{5}{|l|}{ Quintile } \\
\hline & $1 \mathrm{st}$ & $2 \mathrm{nd}$ & $3 \mathrm{rd}$ & 4 th & 5 th \\
\hline \multicolumn{6}{|l|}{ PCBs } \\
\hline In ng/g lipids & $148-627$ & $627-904$ & $904-1,341$ & $1,341-2,330$ & $2,330-101,413$ \\
\hline Cases $(n / n)$ & $189 / 409$ & $211 / 409$ & $257 / 410$ & $291 / 409$ & $321 / 410$ \\
\hline Prevalence (\%) & 46.21 & 51.16 & 62.27 & 71.15 & 78.29 \\
\hline Adjusted OR $(95 \% \mathrm{CI})^{\mathrm{a}}$ & Referent & $0.99(0.73-1.35)$ & $1.52(1.11-2.09)$ & $2.27(1.64-3.15)$ & $2.74(1.92-3.90)$ \\
\hline$p$ value & - & 0.9403 & 0.01 & $<0.001$ & $<0.001$ \\
\hline \multicolumn{6}{|l|}{$\mathrm{HCB}$} \\
\hline In ng/g lipids & $21-214$ & $214-499$ & $499-838$ & $838-1,364$ & $1,364-17,927$ \\
\hline Cases $(n / n)$ & $192 / 409$ & $220 / 409$ & $260 / 410$ & $290 / 409$ & $307 / 410$ \\
\hline Prevalence $(\%)$ & 46.94 & 53.79 & 63.41 & 70.90 & 74.88 \\
\hline Adjusted OR $(95 \% \mathrm{CI})^{\mathrm{a}}$ & Referent & $1.20(0.86-1.68)$ & $1.30(0.89-1.90)$ & $1.62(1.07-2.46)$ & $1.86(1.17-2.95)$ \\
\hline$p$ value & - & 0.2903 & 0.1818 & 0.0231 & 0.0083 \\
\hline \multicolumn{6}{|l|}{$p, p^{\prime}-\mathrm{DDE}$} \\
\hline In ng/g lipids & $54-821$ & $821-1,410$ & $1,410-2,224$ & $2,224-3,605$ & $3,605-22,328$ \\
\hline Cases $(n / n)$ & $175 / 409$ & $226 / 409$ & $265 / 410$ & $284 / 409$ & $319 / 410$ \\
\hline Prevalence $(\%)$ & 42.79 & 55.26 & 64.63 & 69.44 & 77.80 \\
\hline Adjusted OR $(95 \% \mathrm{CI})^{\mathrm{a}}$ & Referent & $1.30(0.96-1.77)$ & $1.66(1.21-2.28)$ & $1.93(1.38-2.69)$ & $2.49(1.74-3.57)$ \\
\hline$p$ value & - & 0.0943 & 0.0019 & 0.0001 & $<0.0001$ \\
\hline \multicolumn{6}{|l|}{$p, p^{\prime}-\mathrm{DDT}$} \\
\hline In ng/g lipids & $4-26$ & $26-39$ & $39-60$ & $60-103$ & $103-940$ \\
\hline Cases $(n / n)$ & $177 / 409$ & $220 / 409$ & $267 / 410$ & $285 / 409$ & $320 / 410$ \\
\hline Prevalence (\%) & 43.28 & 53.79 & 65.12 & 69.68 & 78.05 \\
\hline Adjusted OR $(95 \% \mathrm{CI})^{\mathrm{a}}$ & Referent & $1.17(0.86-1.58)$ & $1.73(1.27-2.36)$ & $1.88(1.37-2.57)$ & $2.48(1.77-3.48)$ \\
\hline$p$ value & - & 0.3127 & 0.0005 & $<0.0001$ & $<0.0001$ \\
\hline \multicolumn{6}{|l|}{$\beta-\mathrm{HCH}$} \\
\hline In ng/g lipids & $3-23$ & $23-37$ & $37-56$ & $56-83$ & $83-781$ \\
\hline Cases $(n / n)$ & $189 / 409$ & $216 / 409$ & $254 / 408$ & $284 / 411$ & $326 / 410$ \\
\hline Prevalence $(\%)$ & 46.21 & 52.81 & 62.25 & 69.10 & 79.51 \\
\hline Adjusted OR $(95 \% \mathrm{CI})^{\mathrm{a}}$ & Referent & $1.08(0.79-1.50)$ & $1.25(0.87-1.80)$ & $1.40(0.95-2.06)$ & $1.97(1.28-3.04)$ \\
\hline$p$ value & - & 0.6299 & 0.2298 & 0.0914 & 0.0021 \\
\hline \multicolumn{6}{|l|}{ Category of POLL5 } \\
\hline Values (sum of orders) & $5-9$ & $6-13$ & $14-17$ & $18-20$ & $21-23$ \\
\hline Cases $(n / n)$ & $170 / 416$ & $212 / 406$ & $307 / 483$ & $256 / 347$ & $324 / 395$ \\
\hline Prevalence (\%) & 40.87 & 52.2 & 63.56 & 73.78 & 82.03 \\
\hline Adjusted OR $(95 \% \mathrm{CI})^{\mathrm{a}}$ & Referent & $1.23(0.99-1.53)$ & $1.75(1.41-2.16)$ & $2.58(2.08-3.19)$ & $3.57(2.88-4.42)$ \\
\hline$p$ value & - & 0.1933 & 0.0007 & $<0.0001$ & $<0.0001$ \\
\hline
\end{tabular}

Unless otherwise specified, values are OR and 95\% CI

${ }^{\text {a }}$ Adjusted for age, sex and BMI

Stepwise factor selection analysis indicated that the effect of $p, p^{\prime}$-DDT on the prevalence of diabetes surpasses that of other POPs, which had to be removed from the model due to low levels of significance associated with their mutual interaction (Table 2). Analysis of the cumulative effect of all five POPs revealed that individuals within the 5th quintile of the POLL5 variable had a more than 2.3fold higher OR of having diabetes (Table 3).

\section{Discussion}

This cross-sectional study conducted in 2,047 adults, among them a considerable number exposed to high occupational and environmental pollution by $\mathrm{PCBs}$ and pesticides, clearly showed that highly increased serum level of five POPs was significantly associated with risk of prediabetes and diabetes in a strongly dose-dependent 
Table 2 Significance of age, sex, BMI and POPs for prediabetes and diabetes

\begin{tabular}{|c|c|c|}
\hline \multirow[t]{2}{*}{ Explanatory variable } & \multicolumn{2}{|l|}{$p$ value } \\
\hline & Prediabetes & Diabetes \\
\hline Age (years) & $<0.001$ & $<0.001$ \\
\hline Sex (male/female) & $<0.001$ & $<0.001$ \\
\hline BMI $\left(\mathrm{kg} / \mathrm{m}^{2}\right)$ & $<0.001$ & $<0.001$ \\
\hline PCBs (categorical) ${ }^{\mathrm{a}}$ & $<0.001$ & - \\
\hline $\begin{array}{l}p, p^{\prime}-\mathrm{DDT}, p, p^{\prime}-\mathrm{DDE}, \beta-\mathrm{HCH}, \mathrm{HCB} \\
\text { (categorical) }^{\mathrm{a}}\end{array}$ & $>0.05$ & - \\
\hline$p, p^{\prime}$-DDT (categorical) ${ }^{\mathrm{a}}$ & - & $<0.0049$ \\
\hline $\begin{array}{l}\text { PCBs, } p, p^{\prime}-\mathrm{DDE}, \beta-\mathrm{HCH}, \mathrm{HCB} \\
\text { (categorical) }^{\mathrm{a}}\end{array}$ & - & $>0.05$ \\
\hline Age (years) ${ }^{\mathrm{c}}$ & $<0.001$ & $<0.001$ \\
\hline Sex $(\text { male/female })^{\mathrm{c}}$ & $<0.001$ & $<0.001$ \\
\hline BMI (categorical) ${ }^{b, c}$ & $<0.001$ & $<0.001$ \\
\hline POLL5 (categorical) ${ }^{\mathrm{a}, \mathrm{c}}$ & $<0.001$ & $<0.0030$ \\
\hline
\end{tabular}

A stepwise factor selection method was used to analyse age, sex and BMI independent significance of each of the five POPs for prediabetes or diabetes. Variables were removed from the model if $p>0.05$

${ }^{a}$ Categories: quintile groups for each POP and for POLL5

${ }^{\mathrm{b}}$ BMI categories $\left(\mathrm{kg} / \mathrm{m}^{2}\right)$ : non-obese $\mathrm{BMI}<30$, obese $\mathrm{BMI}>30$

${ }^{\mathrm{c}}$ Analysis of the cumulative effect of all five POPs using variable POLL5 (sum of orders)

manner. This is in agreement with previous reports on abnormalities in serum insulin [2] or prevalence of selfreported diabetes $[6-8,28-30]$, but also with few recent large cross-sectional studies examining associations of

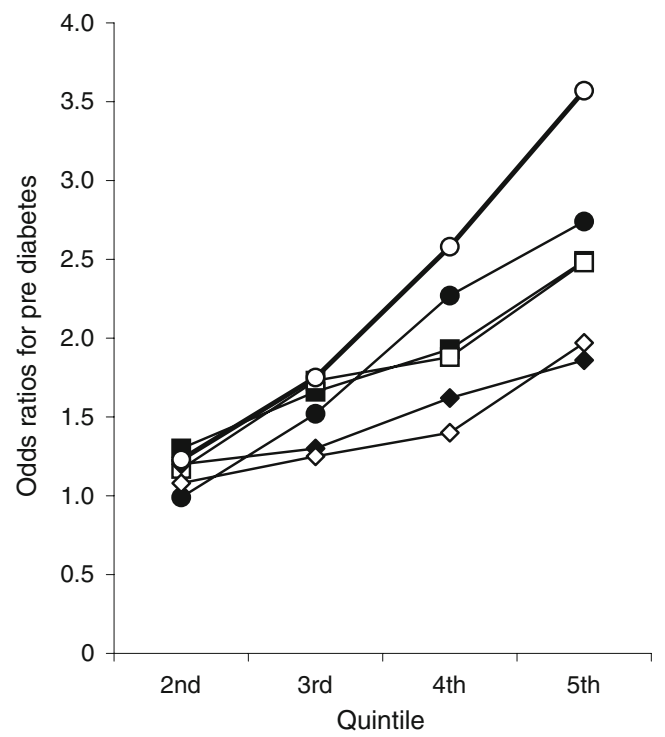

Fig. 1 The prevalence of prediabetes increases with increased circulating levels of POPs. Black circles, PCBs (15 congeners); black squares, $p, p^{\prime}$-DDE; white squares, $p, p^{\prime}$ - DDT; black diamonds, HCB; white diamonds, $\beta-\mathrm{HCH}$; white circles, POLL5 diabetes with chronic exposure to low concentrations of POPs in the general population [11, 31, 32]. Our study strongly differs from the previous investigations in that it examined a large cohort, which had been exposed to high industrial and agricultural pollution, and showed a wide range of $5-95 \%$ POPs' levels, such as $436-$ $5,042 \mathrm{ng} / \mathrm{g}$ lipid for a sum of 15 PCB congeners, 438$6,376 \mathrm{ng} / \mathrm{g}$ for $p, p^{\prime}$-DDE and $99-2,436 \mathrm{ng} / \mathrm{g}$ for $\mathrm{HCB}$ (Table 1). The strength of our study also derives from the diagnosis of impaired fasting glucose/impaired glucose tolerance and diabetes, based in the majority of the population on an OGTT. While FPG was determined in all participants, an OGTT was performed in 1,220 compliant individuals (59.6\% of the cohort), enabling us to study the associations of five POPs with very early changes in glucose metabolism and thus to classify participants as having diabetes and prediabetes. Interestingly, only $32 \%$ of the participants with diabetes were aware of their diabetic status.

We and others had previously observed that presence of the major PCB congeners increases very concordantly, which jeopardised our ability to attribute any particular effect on prevalence of prediabetes or diabetes to one group of PCBs at the exclusion of the others [33]. This prompted us to use the 'whole mixture approach' in which a combination of 15 PCB congeners was investigated as if they were a single agent.

We are aware that indications of causality should be interpreted very carefully in a study with a cross-sectional design, although prospective studies have also indicated a causal relationship between environmental pollution and diabetes. Thus the Agricultural Health Study [9] examined 11,273 wives of licensed pesticide applicators, $506(4.5 \%)$ of whom had gestational diabetes mellitus within 25 years of enrolment, while risk of diabetes was shown to be doubled in those involved in agricultural exposure during the first trimester of pregnancy. The Michigan PBB study (25 years of follow-up) showed increased incidence of diabetes in individuals with a PCB level $>10.0$ parts per billion $(\sim 1,300 \mathrm{ng} / \mathrm{g}$ lipid $)$ [8]. In addition, the 24-year follow-up study of the Yucheng cohort exposed to PCBs and furans in poisoned rice oil in 1974 showed that, in women diagnosed with chloracne and thus exposed to a high level of pollutant, the OR for diabetes was $5.5(95 \%$ CI $2.3-13.4)$ and that for hypertension 3.5 (1.7-7.2) as compared with those who were chloracne-free [34].

We did not find any participants with undetectable POP levels. The relatively high major POP concentrations in our referents do not therefore permit us to contribute to one of the essential questions in this field, namely whether there is a threshold level in the biological activity of individual POPs. We note that the upper limit 
Table 3 Effects of different POPs on the prevalence of diabetes

\begin{tabular}{|c|c|c|c|c|c|}
\hline \multirow[t]{2}{*}{ Analyte } & \multicolumn{5}{|l|}{ Quintile } \\
\hline & $1 \mathrm{st}$ & $2 \mathrm{nd}$ & $3 \mathrm{rd}$ & 4 th & 5 th \\
\hline \multicolumn{6}{|l|}{ PCBs } \\
\hline In ng/g lipids & $148-627$ & $627-903$ & $904-1,341$ & $1,341-2,330$ & $2,330-101,413$ \\
\hline Cases $(n / n)$ & $30 / 409$ & $47 / 409$ & $61 / 410$ & $68 / 409$ & $90 / 410$ \\
\hline Prevalence (\%) & 7.33 & 11.49 & 14.88 & 16.63 & 21.95 \\
\hline Adjusted OR $(95 \% \mathrm{CI})^{\mathrm{a}}$ & Referent & $1.32(0.77-2.26)$ & $1.64(0.96-2.80)$ & $1.77(1.05-3.02)$ & $1.86(1.09-3.17)$ \\
\hline$p$ value & - & 0.3154 & 0.0692 & 0.0335 & 0.0223 \\
\hline \multicolumn{6}{|l|}{$\mathrm{HCB}$} \\
\hline In ng/g lipids & $21-214$ & $214-499$ & $499-838$ & $838-1,364$ & $1,364-17,927$ \\
\hline Cases $(n / n)$ & $25 / 409$ & $28 / 409$ & $61 / 410$ & $80 / 409$ & $102 / 410$ \\
\hline Prevalence $(\%)$ & 6.11 & 6.85 & 14.88 & 19.56 & 24.88 \\
\hline Adjusted OR $(95 \% \mathrm{CI})^{\mathrm{a}}$ & Referent & $0.63(0.33-1.17)$ & $0.94(0.52-1.70)$ & $1.21(0.66-2.23)$ & $1.25(0.64-2.43)$ \\
\hline$p$ value & - & 0.1428 & 0.8359 & 0.5342 & 0.5154 \\
\hline \multicolumn{6}{|l|}{$p, p^{\prime}-\mathrm{DDE}$} \\
\hline In ng/g lipids & $54-821$ & $821-1,410$ & $1,410-2,224$ & $2,224-3,605$ & $3,605-22,328$ \\
\hline Cases $(n / n)$ & $23 / 409$ & $43 / 409$ & $67 / 410$ & $61 / 409$ & $102 / 410$ \\
\hline Prevalence $(\%)$ & 5.62 & 10.51 & 16.34 & 14.91 & 24.88 \\
\hline Adjusted OR $(95 \% \mathrm{CI})^{\mathrm{a}}$ & Referent & $1.43(0.80-2.56)$ & $1.85(1.06-3.21)$ & $1.34(0.76-2.35)$ & $1.94(1.11-3.78)$ \\
\hline$p$ value & - & 0.288 & 0.0299 & 0.3117 & 0.0198 \\
\hline \multicolumn{6}{|l|}{$p, p^{\prime}-\mathrm{DDT}$} \\
\hline In ng/g lipids & $4-26$ & $26-39$ & $39-60$ & $60-103$ & $103-940$ \\
\hline Cases $(n / n)$ & $18 / 409$ & $42 / 409$ & $56 / 410$ & $80 / 409$ & $100 / 410$ \\
\hline Prevalence (\%) & 4.4 & 10.27 & 13.66 & 19.56 & 24.39 \\
\hline Adjusted OR $(95 \% \mathrm{CI})^{\mathrm{a}}$ & Referent & $1.57(0.86-2.86)$ & $1.84(1.03-2.27)$ & $2.51(1.43-4.38)$ & $2.49(1.42-4.35)$ \\
\hline$p$ value & - & 0.14254 & 0.0385 & 0.0013 & 0.0014 \\
\hline \multicolumn{6}{|l|}{$\beta-\mathrm{HCH}$} \\
\hline In ng/g lipids & $3-23$ & $23-37$ & $37-56$ & $56-83$ & $83-781$ \\
\hline Cases $(n / n)$ & $26 / 409$ & $37 / 409$ & $49 / 408$ & $70 / 411$ & $114 / 410$ \\
\hline Prevalence $(\%)$ & 6.36 & 9.05 & 12.01 & 17.03 & 27.80 \\
\hline Adjusted OR $(95 \% \mathrm{CI})^{\mathrm{a}}$ & Referent & $0.90(0.50-1.60)$ & $0.77(0.43-1.37)$ & $0.91(0.51-1.62)$ & $1.08(0.59-1.97)$ \\
\hline$p$ value & - & 0.7135 & 0.3706 & 0.7373 & 0.8018 \\
\hline \multicolumn{6}{|l|}{ Category of POLL5 } \\
\hline Values (sum of orders) & $5-9$ & $10-13$ & $14-17$ & $18-20$ & $21-23$ \\
\hline Cases $(n / n)$ & $20 / 416$ & $39 / 406$ & $56 / 483$ & $62 / 347$ & $119 / 395$ \\
\hline Prevalence (\%) & 4.81 & 9.61 & 11.59 & 17.87 & 30.13 \\
\hline Adjusted OR $(95 \% \mathrm{CI})^{\mathrm{a}}$ & Referent & $1.21(0.65-2.25)$ & $1.03(0.59-2.02)$ & $1.57(0.84-2.91)$ & $2.37(1.27-4.39)$ \\
\hline$p$ value & - & 0.5406 & 0.7836 & 0.1520 & 0.0064 \\
\hline
\end{tabular}

Unless otherwise specified, values are OR and 95\% CI

${ }^{a}$ Adjusted for age, sex and BMI

of PCBs of $627 \mathrm{ng} / \mathrm{g}$ lipid in our first (referent) PCBs quintile is about four times higher than that of $164 \mathrm{ng} / \mathrm{g}$ lipid reported for the 90th percentile in the NHANES Study [11]; similarly, the upper limit of $p, p^{\prime}$-DDE of 821 $\mathrm{ng} / \mathrm{g}$ lipid in our first quintile is still slightly higher than that of the 75 th percentile $(717 \mathrm{ng} / \mathrm{g}$ lipid) by the same authors. Since the selection of the reference group appears critical for the statistical evaluation, such relatively high POP levels in our referents have apparently resulted in lower ORs in the upper quintiles of individual POPs than those found in the NHANES Study [11].

Circulating lipids might significantly influence transport and tissue distribution of POPs. We previously reported significant association of PCBs, $p, p^{\prime}$-DDE and $\mathrm{HCB}$ with circulating triacylglycerol and of $p, p^{\prime}$-DDE and $\mathrm{HCB}$ with total cholesterol [21]. Similar an association of PCBs 
$(\sim 600 \mathrm{ng} / \mathrm{g})$ with triacylglycerol and cholesterol was recently found [35].

It has been repeatedly observed that high exposure to environmental toxicants is linked to an increased risk of diabetes. Nevertheless, molecular mechanisms explaining such associations are lacking. The most likely mechanism is one involving tissue specific up- or downregulation of gene expression, which might promote glucose intolerance and induce diabetes. It is well known that the toxic effects of several POPs are mediated via binding with aryl hydrocarbon receptor (AhR), a ligand-activated transcription factor. It has been suggested that this receptor may promote diabetogenesis by antagonising the functions of peroxisome proliferator-activated receptors, which were recently found to be linked to cellular proliferation, differentiation and apoptosis, as well as to obesity, diabetes, atherosclerosis, inflammation, cancer and ageing [1]. Vezina et al. [36] observed that transcriptional response to administration of different AhR agonists (TCDD, pentachlorodibenzofuran and $\mathrm{PCB} 126)$ was distinctly dissimilar, indicating that different agonists have clearly specific actions. In addition, the hepatic gene expression profile for PCB153, which is not an AhR agonist, was extensive and very different from those for each of the aforementioned AhR agonists.

It has been hypothesised that the diabetogenic action of POPs could be associated with inhibition of glucose transport. In dioxin-treated mice, reduced glucose transport activity was found together with reduced copy number of the glucose transporter GLUT4 and its mRNA [37]. It was recently proposed that the ratio of GLUT4 (also known as SLC2A4) mRNA to nuclear transcription factor kappa B mRNA in adipose tissue obtained from Vietnam veterans appears to be the most sensitive and reliable indicator of dioxin-induced diabetes, particularly at very low exposure levels, suggesting that the diabetogenic shift occurs in the biochemistry of adipose tissue [4]. However, a recent study of the Greenland population observed no associations between POPs and stages of glucose intolerance or markers of insulin resistance, indicating instead that POPs may affect insulin secretion [38].

Moreover, an alternative pathway has also been sought, which is predominantly focused on the association between the serum level of $\gamma$-glutamyltransferase and risk of type 2 diabetes. This was shown in a prospective cohort study in 20,158 Finnish adults followed-up for an average of 12.7 years [39] and a similar DESIR study in 5,212 French adults [40]. Results of these studies indicate that the association between serum $\gamma$-glutamyltransferase and type 2 diabetes was stronger in obesity and that obesity could not predict the risk of type 2 diabetes among participants with $\gamma$-glutamyltransferase at the low end of the normal range. This observation led to the hypothesis that the association of $\gamma$-glutamyltransferase with type 2 diabetes reflects exposure to POPs, since these reside in adipose tissue as endocrine disruptors and thus may interact with obesity to cause type 2 diabetes [41].

In conclusion, we found that increasing serum concentrations of all individual POPs were associated with progressive increase in prevalence of prediabetes and that increasing levels of PCBs, $p, p^{\prime}$-DDE and $p, p^{\prime}$-DDT, but not of $\mathrm{HCB}$ and $\beta-\mathrm{HCH}$ were associated with increased prevalence of diabetes. In addition, this study showed a synergistic effect of the five POPs in determining the prevalence of prediabetes and diabetes in the general population of Eastern Slovakia.

Acknowledgements A great part of this work was supported by the 5th Framework Program of the European Commission (PCBRISKQLK4-2000-00488) and by the MVTS/QLK4-2000-00488 fund of the Slovak Academy of Sciences. The authors would also like to acknowledge support from the Slovak Diabetes Association, COST BM0602 and COST FA0602. The authors wish to express their cordial gratitude to all district physicians who participated in the field surveys, as well as to R. Imrich and L. Ksinantova for invaluable clinical fieldwork, to A. Mitková for skilful technical assistance and to our colleague B. Ukropcová from the Institute of Experimental Endocrinology for a critical reading of the manuscript.

Duality of interest The authors declare that there is no duality of interest associated with this manuscript.

\section{References}

1. Remillard RB, Bunce NJ (2002) Linking dioxins to diabetes: epidemiology and biologic plausibility. Environ Health Perspect 110:853-858

2. Henriksen GL, Ketchum NS, Michalek JE, Swaby JA (1997) Serum dioxin and diabetes mellitus in veterans of Operation Ranch Hand. Epidemiology 8:252-258

3. Kern PA, Said S, Jackson WG Jr, Michalek JE (2004) Insulin sensitivity following agent orange exposure in Vietnam veterans with high blood levels of 2,3,7,8-tetrachlorodibenzo- $p$-dioxin. J Clin Endocrinol Metab 89:4665-4672

4. Fujiyoshi PT, Michalek JE, Matsumura F (2006) Molecular epidemiologic evidence for diabetogenic effects of dioxin exposure in U.S. Air force veterans of the Vietnam war. Environ Health Perspect 114:1677-1683

5. Michalek JE, Akhtar FZ, Kiel JL (1999) Serum dioxin, insulin, fasting glucose, and sex hormone-binding globulin in veterans of Operation Ranch Hand. J Clin Endocrinol Metab 84:1540 1543

6. Bertazzi PA, Bernucci I, Brambilla G, Consonni D, Pesatori AC (1998) The Seveso studies on early and long-term effects of dioxin exposure: a review. Environ Health Perspect 106(Suppl 2):625-633

7. Steenland K, Piacitelli L, Deddens J, Fingerhut M, Chang LI (1999) Cancer, heart disease, and diabetes in workers exposed to 2,3,7,8tetrachlorodibenzo-p-dioxin. J Natl Cancer Inst 91:779-786

8. Rignell-Hydbom A, Rylander L, Hagmar L (2007) Exposure to persistent organochlorine pollutants and type 2 diabetes mellitus. Hum Exp Toxicol 26:447-452

9. Saldana TM, Basso O, Hoppin JA et al (2007) Pesticide exposure and self-reported gestational diabetes mellitus in the Agricultural Health Study. Diabetes Care 30:529-534 
10. Vasiliu O, Cameron L, Gardiner J, Deguire P, Karmaus W (2006) Polybrominated biphenyls, polychlorinated biphenyls, body weight, and incidence of adult-onset diabetes mellitus. Epidemiology 17:352-359

11. Lee DH, Lee IK, Song K et al (2006) A strong dose-response relation between serum concentrations of persistent organic pollutants and diabetes: results from the National Health and Examination Survey 1999-2002. Diabetes Care 29:1638-1644

12. Calvert GM, Sweeney MH, Deddens J, Wall DK (1999) Evaluation of diabetes mellitus, serum glucose, and thyroid function among United States workers exposed to 2,3,7,8tetrachlorodibenzo- $p$-dioxin. Occup Environ Med 56:270-276

13. Codru N, Schymura MJ, Negoita S, Rej R, Carpenter DO (2007) Diabetes in relation to serum levels of polychlorinated biphenyls and chlorinated pesticides in adult Native Americans. Environ Health Perspect 115:1442-1447

14. Kocan A, Petrik J, Drobna B, Chovancova J (1994) Levels of PCBs and some organochlorine pesticides in the human population of selected areas of the Slovak Republic. I. Blood. Chemosphere 29:2315-2325

15. Kocan A, Petrik J, Jursa S, Chovancova J, Drobna B (2001) Environmental contamination with polychlorinated biphenyls in the area of their former manufacture in Slovakia. Chemosphere 43:595-600

16. Jursa S, Chovancova J, Petrik J, Loksa J (2006) Dioxin-like and non-dioxin-like PCBs in human serum of Slovak population. Chemosphere 64:686-691

17. Hovander L, Linderholm L, Athanasiadou M et al (2006) Levels of PCBs and their metabolites in the serum of residents of a highly contaminated area in eastern Slovakia. Environ Sci Technol 40:3696-3703

18. Langer P, Kocan A, Tajtakova $M$ et al (2008) Increased thyroid volume, prevalence of thyroid antibodies and impaired fasting glucose in young adults from organochlorine cocktail polluted area: outcome of transgenerational transmission? Chemosphere 73:1145-1150

19. Langer P, Kocan A, Tajtakova M et al (2007) Possible effects of persistent organochlorinated pollutants cocktail on thyroid hormone levels and pituitary-thyroid interrelations. Chemosphere 70:110-118

20. Langer P, Tajtakova M, Fodor G et al (1998) Increased thyroid volume and prevalence of thyroid disorders in an area heavily polluted by polychlorinated biphenyls. Eur J Endocrinol 139:402-409

21. Langer P, Tajtakova M, Kocan A et al (2007) Thyroid ultrasound volume, structure and function after long-term high exposure of large population to polychlorinated biphenyls, pesticides and dioxin. Chemosphere 69:118-127

22. Radikova Z, Tajtakova M, Kocan A et al (2008) Possible effects of environmental nitrates and toxic organochlorines on human thyroid in highly polluted areas in Slovakia. Thyroid 18:353-362

23. Langer P, Kocan A, Tajtakova M et al (2009) Multiple adverse thyroid and metabolic health signs in the population from the area heavily polluted by organochlorine cocktail (PCB, DDE, HCB, dioxin). Thyroid Res 2:3

24. Park JS, Bergman A, Linderholm L et al (2008) Placental transfer of polychlorinated biphenyls, their hydroxylated metabolites and pentachlorophenol in pregnant women from eastern Slovakia. Chemosphere 70:1676-1684

25. Park HY, Hertz-Picciotto I, Petrik J, Palkovicova L, Kocan A, Trnovec T (2008) Prenatal PCB exposure and thymus size at birth in neonates in Eastern Slovakia. Environ Health Perspect 116:104-109
26. Jan J, Sovcikova E, Kocan A, Wsolova L, Trnovec T (2007) Developmental dental defects in children exposed to PCBs in eastern Slovakia. Chemosphere 67:S350-354

27. No authors listed (2008) Diagnosis and classification of diabetes mellitus. Diabetes Care 31(Suppl 1):S55-S60

28. Cox S, Niskar AS, Narayan KM, Marcus M (2007) Prevalence of self-reported diabetes and exposure to organochlorine pesticides among Mexican Americans: Hispanic health and nutrition examination survey, 1982-1984. Environ Health Perspect $115: 1747-1752$

29. Rylander L, Rignell-Hydbom A, Hagmar L (2005) A crosssectional study of the association between persistent organochlorine pollutants and diabetes. Environ Health 4:28

30. Vena J, Boffetta P, Becher H et al (1998) Exposure to dioxin and nonneoplastic mortality in the expanded IARC international cohort study of phenoxy herbicide and chlorophenol production workers and sprayers. Environ Health Perspect 106(Suppl 2):645653

31. Everett CJ, Frithsen IL, Diaz VA, Koopman RJ, Simpson WM Jr, Mainous AG 3rd (2007) Association of a polychlorinated dibenzo- $p$-dioxin, a polychlorinated biphenyl, and DDT with diabetes in the 1999-2002 National Health and Nutrition Examination Survey. Environ Res 103:413-418

32. Lee DH, Lee IK, Porta M, Steffes M, Jacobs DR Jr (2007) Relationship between serum concentrations of persistent organic pollutants and the prevalence of metabolic syndrome among nondiabetic adults: results from the National Health and Nutrition Examination Survey 1999-2002. Diabetologia 50:1841-1851

33. Carpenter DO (2008) Environmental contaminants as risk factors for developing diabetes. Rev Environ Health 23:59-74

34. Wang SL, Tsai PC, Yang CY, Leon Guo Y (2008) Increased risk of diabetes and polychlorinated biphenyls and dioxins: a 24-year follow-up study of the Yucheng cohort. Diabetes Care 31:15741579

35. Goncharov A, Haase RF, Santiago-Rivera A et al (2008) High serum PCBs are associated with elevation of serum lipids and cardiovascular disease in a Native American population. Environ Res 106:226-239

36. Vezina CM, Walker NJ, Olson JR (2004) Subchronic exposure to TCDD, PeCDF, PCB126, and PCB153: effect on hepatic gene expression. Environ Health Perspect 112:1636-1644

37. Liu PC, Matsumura F (1995) Differential effects of 2,3,7,8tetrachlorodibenzo- $p$-dioxin on the "adipose-type" and "braintype" glucose transporters in mice. Mol Pharmacol 47:65-73

38. Jørgensen ME, Borch-Johnsen K, Bjerregaard P (2008) A crosssectional study of the association between persistent organic pollutants and glucose intolerance among Greenland Inuit. Diabetologia 51:1416-1422

39. Lee DH, Silventoinen K, Jacobs DR Jr, Jousilahti P, Tuomileto J (2004) gamma-Glutamyltransferase, obesity, and the risk of type 2 diabetes: observational cohort study among 20, 158 middle-aged men and women. J Clin Endocrinol Metab 89:5410-5414

40. Andre P, Balkau B, Born C, Charles MA, Eschwege E (2006) Three-year increase of gamma-glutamyltransferase level and development of type 2 diabetes in middle-aged men and women: the D.E.S.I.R. cohort. Diabetologia 49:2599-2603

41. Lee DH, Steffes MW, Jacobs DR Jr (2008) Can persistent organic pollutants explain the association between serum gammaglutamyltransferase and type 2 diabetes? Diabetologia 51:402407 